\title{
Enhancing Mobile Satisfaction through Integration of Usability and Flow
}

\author{
Chia-Liang Hung ${ }^{1}$, Jerome Chih-Lung Chou ${ }^{2} \&$ Chung-Ming Ding ${ }^{1}$ \\ ${ }^{1}$ Department of Information Management, School of Management, National Chi Nan University, Taiwan \\ ${ }^{2}$ Department of Information Management, Hwa-Hsia Institute of Technology, Taiwan \\ Correspondence: Chia-Liang Hung, Department of Information Management, School of Management, National \\ Chi Nan University, 470, University Rd., Puli, Nantou County 545, Taiwan, R.O.C.. Tel: 886-49-291-0960 ext. \\ 4640. E-mail: clhung@ncnu.edu.tw
}

Received: February 22, 2012

Accepted: March 28, 2012 Published: May 1, 2012

doi:10.5539/emr.v1n1p44

URL: http://dx.doi.org/10.5539/emr.v1n1p44

\begin{abstract}
This research examines the influence of usability and flow on user satisfaction of mobile gaming. Two structural equation models test the influences resulted from usability and flow and compare differences between two main types of mobile games, the RPG/adventure and causal/puzzle types preferred most in Taiwan. The results show that the integrative model of usability and flow explains user mobile satisfaction well. Accordingly, this paper discusses strategies for enhancing user mobile satisfaction by achieving usability and flow experience through collaboration among three important complementary mobile players: game vendors, mobile phone manufactures, and mobile network operators.
\end{abstract}

Keywords: mobile game, usability, flow, satisfaction

\section{Introduction}

\subsection{Research Background}

The use of handheld devices has undergone recent dramatic growth, with 172 million devices sold in 2009 and a yearly global market growth rate of approximately $20 \%$ (Pettey \& Tudor, 2010). Factors contributing to this impressive growth include the ability of the device to increase connectivity among individuals and their flexibility to satisfy a wide range of needs, including entertainment (Constantiou et al., 2007). Mobile broadband penetration has enabled mobile games to gradually increase from causal games, puzzles, RPG (role playing game), to even Monopoly. Playing mobile games on handheld devices through wireless networks anytime and anywhere is more convenient than playing PC games on fixed-line Internet. Consequently, Microsoft, Google, and Apple have launched their mobile services in confronting RIM (the vendor of Blackberry) and Nokia (Reisinger, 2009; 2010). However, the network value of mobile system includes system vendors, operators, value-added integrators, device vendors, and service distributors (Steinbock, 2002). Most mobile gaming developers are relatively small-scale, new-born, and lack bargaining power (Multimedia Research Consultancy, 2008; Pyramid Research, 2009). Growth of the mobile gaming industry necessitates strategic collaboration between complements to provide the whole product/service to users (Teece, 1986; Venkatesh \& Ramesh, 2006; Mohr et al., 2010). The triple cooperative relationship among mobile game developers, mobile device vendors, and mobile operators is an important issue for researchers and practitioners and indispensable to promote the mobile experience of users (Messerschmitt \& Szypersk, 2003; Rai \& Sambamurthy, 2006; Hung \& Yeh, 2007).

\subsection{Research Motivation}

Mobile game enterprises face an aggressively dynamic market place with a low survival rate (Multimedia Research Consultancy, 2008). Only 53\% of mobile enterprises last five years or more, and $17 \%$ of that last seven years or more (Multimedia Research Consultancy, 2008). Many emerging mobile applications lack a user-centric focus (Zhang et al., 2008). Venkatesh et al. (2003) pointed out that the mobile context such as a small-sized screen, limited screen resolution and power consumption, and cumbersome input mechanisms limits mobile applications. Thus, mobile applications should support easy-to-use interfaces (Beck \& Wade, 2003). Kassulke (2007) also argued that mobile gaming strategies should not simply move causal games from the PC-based or 
fixed-line Internet platform to that of handheld devices or mobile phones. Davis (1989) developed the wildly used Technology Acceptance Model (TAM) to explain the issue of technology diffusion. However, it is unsuitable for interactive and entertainment technologies such as mobile services (Hsu \& Lu, 2003; Klimmt et al., 2009). Therefore, this research explored design factors that shape mobile gaming and thus influence mobile gamer adoption.

\section{Literature Review}

The study of mobile gaming applies concepts of usability and flow experience that have constituted research of human-computer interaction (HCI) (Nielsen, 1994a; Pace, 2004; Pilke, 2004; Noiwan \& Norcio, 2006; Choi et al., 2007; Edwards et al., 2008; Lee et al., 2010). The former originating from Nielsen has been widely used in the interface design of artifacts (Nielsen, 1994a). The latter developed by Csikszentmihalyi, has been applied to fields of gaming, social/religious convensions, sports, and e-commerce shopping (Csikszentmihalyi, 1975; Csikszentmihalyi, 1990; Hoffman \& Novak, 1996; Koufaris, 2002).

\subsection{Definition of Usability}

The conceptual definition of usability by ISO (International Organization for Standardization) 9241-11 is the extent to which a product can be used to achieve specified goals with effectiveness, efficiency, and satisfaction in a specified context of use (Karat, 1997; Agarwal \& Venkatesh, 2002; Sauro \& Kindlund, 2005; Whitehead, 2006; Peevers et al., 2007). Usability means the use quality of a system for a user to achieve his/her own purpose after a series of tasks. Higher system usability guides users to their own challengeable objectives. The operational definition of usability, that is, the heuristic evaluation framework of usability by Nielsen dominates (Gray \& Salzman, 1998). This definition includes visibility of system status, match between the system and the real world, user control and freedom, consistency and standards, error prevention, recognition rather than recall, flexibility and efficiency of use, aesthetic and minimalist design, and helping users recognize, diagnose, and recover from errors (Nielsen, 1994a). Nielsen (1994b) further grouped the framework into five usability goals: learnability, efficiency, memorability, errors (as in low error rate), and satisfaction. The importance of usability has driven Microsoft to define MUG (Microsoft usability guidelines) to increase website appeal (Keeker, 1997). Venkatesh and Ramesh (2006) empirically tested the MUG-based model in wireless sites and concluded that it outperforms the widely employed TAM. Nielsen and Loranger (2006 also articulated web designing rules using usability. Many researchers shown in Table 1 apply usability to cases of interactive innovation and have recently applied Nielsen usability to analyze innovation interfaces such as the Apple iphone and ipad (Budiu \& Nielsen, 2010).

\subsection{Flow Experience}

Csikszentmihalyi (1975) described flow as a psychologically optimal experience: the holistic experience that people feel when they act with total involvement. The term "optimal experience" refers to those occasions where people feel a deep sense of exhilaration and enjoyment and an inner harmony even when stretching the limits (Csikszentmihalyi, 1975). Hence, to remain in flow, one must develop skills to meet new challenges according to a continuous and self-reinforcing feedback mechanism (Csikszentmihalyi \& Csikszentmihalyi, 1988; Massimini \& Carli, 1988; Clarke \& Haworth, 1994). When indulged in flow, people enjoy a series of fluent activities such as artistic performance, game playing, and rituals with a distorted sense of time, loss of self-awareness, and a feeling of transcendence and complete immersion (Csikszentmihalyi \& Csikszentmihalyi, 1988; Lutz \& Guiry, 1994).

Csikszentmihalyi (1990) articulated eight elements that help fullfill the flow experience. First, clear goals and immediate feedbacks. Second, a good balance between challenging tasks and personal skills. Third, increasing awareness that stimulates subsequent actions and contributes to learning. Fourth, concentration that increases the pleasurable feeling. Fifth, a sense of control that helps achieve a flow state. Sixth, loss of self-consciousness that enhances the indulgence feeling. Seventh, time distortion that immerses players in games without worries and pressure. Eighth, the autotelic experience that intrinsically motivates what a person is doing. The flow elements of Csikszentmihalyi have been widely employed to measure design flow (Trevino \& Webster, 1992; Webster et al., 1993; Ghani \& Deshpand, 1994; Hoffman \& Novak, 1996; Novak et al., 2000; Moon \& Kim, 2001; Koufaris, 2002; Sweetser \& Wyeth, 2005; Klimmt et al., 2007; Chen et al., 2008a; Chen et al., 2008b; Weibel et al., 2008). Table 2 shows several studies on flow constructs ranging from concentration, matching between skill and challenge, controllability, clear goals, feedback, immersion, to social interactions in their cases respectively.

\section{Research Design}

\subsection{Research Framework}

This research designed a framework of influences from usability and flow to mobile gaming satisfaction. 
Figure 1 shows the four properties that measure mobile usability, while seven ones test the mobile flow experience.

\subsection{Measurements of Mobile Usability}

Table 3 shows question items designed by this research to measure usability. The learnability construct focuses on familiar interfaces and logical procedures. Question items of efficiency range from exploration loadings, agility, to expected response. The error property emphasizes error prevention and reckoning. Finally, question items of memorability concern facilitating environmental settings and problem solving.

Table 1. Studies on usability of innovations

\begin{tabular}{|c|c|c|}
\hline Study & Main issue & Usability measurements \\
\hline $\begin{array}{l}\text { Buchanan et al. } \\
\text { (2001) }\end{array}$ & $\begin{array}{l}\text { Enhancing the } \\
\text { usability of mobile } \\
\text { Internet }\end{array}$ & $\begin{array}{l}\text { Focusing on properties of efficiency and ease of use to increase WAP } \\
\text { usability when faced with common mobile problems such as small } \\
\text { screen size, navigation and site structure, and input methods. }\end{array}$ \\
\hline $\begin{array}{l}\text { Venkatesh et al. } \\
\text { (2003) }\end{array}$ & $\begin{array}{l}\text { Exploring the } \\
\text { usability of mobile } \\
\text { commerce }\end{array}$ & $\begin{array}{l}\text { Using the MUG framework to measure performance caused by } \\
\text { informational relevance, structure, and personalized mobile commerce. }\end{array}$ \\
\hline $\begin{array}{l}\text { Ardito et al. } \\
(2004)\end{array}$ & $\begin{array}{l}\text { Focusing on the } \\
\text { usability of digital } \\
\text { learning }\end{array}$ & $\begin{array}{l}\text { Building e-learning tools using the ISO usability criteria to reach a high } \\
\text { degree of usability performance in four functions: presentation, } \\
\text { hypermediality, application proactivity, and user activity. }\end{array}$ \\
\hline $\begin{array}{l}\text { Wilson et al. } \\
(2004)\end{array}$ & $\begin{array}{l}\text { Studying the usability } \\
\text { of e-encyclopedia }\end{array}$ & $\begin{array}{l}\text { Focusing on Nielsen memorability and satisfaction to measure } \\
\text { recognition, recall, quality, ease of use, likeability, and user affect after } \\
\text { using e-encyclopedias. }\end{array}$ \\
\hline $\begin{array}{l}\text { Ryan and } \\
\text { Gonsalves } \\
(2005)\end{array}$ & $\begin{array}{l}\text { Examining the } \\
\text { context effect on } \\
\text { mobile usability } \\
\text { between different } \\
\text { platforms }\end{array}$ & $\begin{array}{l}\text { Applying the four usability goals of Nielson plus context awareness to } \\
\text { examine the quality of mobile usability between PC-web, PC-device, } \\
\text { mobile-web, and mobile-device applications }\end{array}$ \\
\hline $\mathrm{Su}(2006)$ & $\begin{array}{l}\text { Developing usability } \\
\text { guidelines for mobile } \\
\text { learning portals }\end{array}$ & $\begin{array}{l}\text { Measuring mobile learning usability based on the ISO definition of } \\
\text { efficiency and effectiveness, Nielsen's guidelines, and, especially, } \\
\text { mobile context awareness and dynamicity that focus on the visibility of } \\
\text { status and cognitive load of interactions under a small-sized display } \\
\text { interfacing context. }\end{array}$ \\
\hline $\begin{array}{l}\text { Peevers et al. } \\
(2007)\end{array}$ & $\begin{array}{l}\text { Comparing usability } \\
\text { between different } \\
\text { SMS banking } \\
\text { services }\end{array}$ & $\begin{array}{l}\text { Measuring the usability of SMS banking services by the ISO usability: } \\
\text { efficiency and effectiveness, and Nielsen's criteria: completion, errors } \\
\text { and satisfaction. }\end{array}$ \\
\hline $\begin{array}{l}\text { Bernhaupt et al. } \\
\text { (2007) }\end{array}$ & $\begin{array}{l}\text { Lessons from iTV } \\
\text { usability experiments }\end{array}$ & $\begin{array}{l}\text { Evaluating the user-centric design of interactive TV based on the } \\
\text { Nielsen heuristic usability evaluation: simplicity, learnability, and } \\
\text { familiarity of interactions. }\end{array}$ \\
\hline $\begin{array}{l}\text { Looije et al. } \\
(2007)\end{array}$ & $\begin{array}{l}\text { Usability engineering } \\
\text { of mobile map } \\
\text { application }\end{array}$ & $\begin{array}{l}\text { A study combined Nielsen usability, trust, technology acceptance, with } \\
\text { situational awareness for measuring the usability of the 3D mobile map } \\
\text { on tourist information and navigation. }\end{array}$ \\
\hline
\end{tabular}


Table 2. Studies on flow experience of innovations

\begin{tabular}{|c|c|c|}
\hline Study & Main issue & Flow measurements \\
\hline $\begin{array}{l}\text { Trevino and } \\
\text { Webster (1992) }\end{array}$ & $\begin{array}{l}\text { Measuring user evaluation } \\
\text { and perceived impacts of } \\
\text { computer-mediated } \\
\text { communication } \\
\text { technologies }\end{array}$ & $\begin{array}{l}\text { Increasing flow using computer-mediated communication } \\
\text { technologies from ease of use, management support, partner } \\
\text { medium use, playfulness, and exploration. }\end{array}$ \\
\hline $\begin{array}{l}\text { Webster et al. } \\
\text { (1993) }\end{array}$ & $\begin{array}{l}\text { Measuring flow factors in } \\
\text { electronic media and } \\
\text { computing tools }\end{array}$ & $\begin{array}{l}\text { Increasing flow by adding more playfulness including control, } \\
\text { attention focus, curiosity, intrinsic interest, flexibility, } \\
\text { experimentation, and modifiability in human-computer interactions. }\end{array}$ \\
\hline $\begin{array}{l}\text { Ghani and } \\
\text { Deshpande } \\
\text { (1994) }\end{array}$ & $\begin{array}{l}\text { Studying the task } \\
\text { designing in the } \\
\text { human-computer } \\
\text { interaction }\end{array}$ & $\begin{array}{l}\text { Enhancing flow by higher perceived control and computer interface } \\
\text { challenges, and motivating exploratory use. }\end{array}$ \\
\hline $\begin{array}{l}\text { Hoffman and } \\
\text { Novak (1996) }\end{array}$ & $\begin{array}{l}\text { Conceptual foundations for } \\
\text { hypermedia CME } \\
\text { environments }\end{array}$ & $\begin{array}{l}\text { Evaluating the flow of network navigation by criteria of a seamless } \\
\text { sequence of responses of machine interactivity, intrinsic enjoyment, } \\
\text { loss of self-consciousness, and a self-reinforcing mechanism. }\end{array}$ \\
\hline $\begin{array}{l}\text { Novak et al. } \\
(2000)\end{array}$ & $\begin{array}{l}\text { Maximize user online } \\
\text { experience }\end{array}$ & $\begin{array}{l}\text { Enhancing the flow of web browsing by installing a greater feeling } \\
\text { of controllability, challenges, focused attention, and telepresence. }\end{array}$ \\
\hline $\begin{array}{l}\text { Moon and Kim } \\
\text { (2001) }\end{array}$ & $\begin{array}{l}\text { Enhancing the adoption of } \\
\text { WWW }\end{array}$ & $\begin{array}{l}\text { Increasing flow of web pages by criteria of easy to explore, full of } \\
\text { fun and curiosity, and arousing imagination. }\end{array}$ \\
\hline $\begin{array}{l}\text { Koufaris } \\
(2002)\end{array}$ & $\begin{array}{l}\text { Interface design of Online } \\
\text { shopping website }\end{array}$ & $\begin{array}{l}\text { Higher shopping process involvement, more skillful and } \\
\text { challenging web surfing; more value-added search mechanisms, } \\
\text { more online shopping enjoyment, and higher user intention to } \\
\text { return. }\end{array}$ \\
\hline $\begin{array}{l}\text { Sweetser and } \\
\text { Wyeth (2005) }\end{array}$ & $\begin{array}{l}\text { Evaluating player } \\
\text { enjoyment in games }\end{array}$ & $\begin{array}{l}\text { Augmenting the flow definition of Csikszentmihalyi by the typical } \\
\text { characteristic of online networking games: social interaction. }\end{array}$ \\
\hline $\begin{array}{l}\text { Chen et al. } \\
(2008 b)\end{array}$ & $\begin{array}{l}\text { Determining the } \\
\text { relationship between flow } \\
\text { factor and communication } \\
\text { outcomes }\end{array}$ & $\begin{array}{l}\text { Measuring flow of communication under a web context by } \\
\text { controllability, attention focus, and curiosity and interest. }\end{array}$ \\
\hline $\begin{array}{l}\text { Weibel et al. } \\
(2008)\end{array}$ & $\begin{array}{l}\text { Examining the role of } \\
\text { human-controlled } \\
\text { opponents in multi-player } \\
\text { games }\end{array}$ & $\begin{array}{l}\text { Enhancing the flow of online gaming using a human-controlled } \\
\text { interface of social interaction, higher levels of presence, and } \\
\text { enjoyment. }\end{array}$ \\
\hline
\end{tabular}

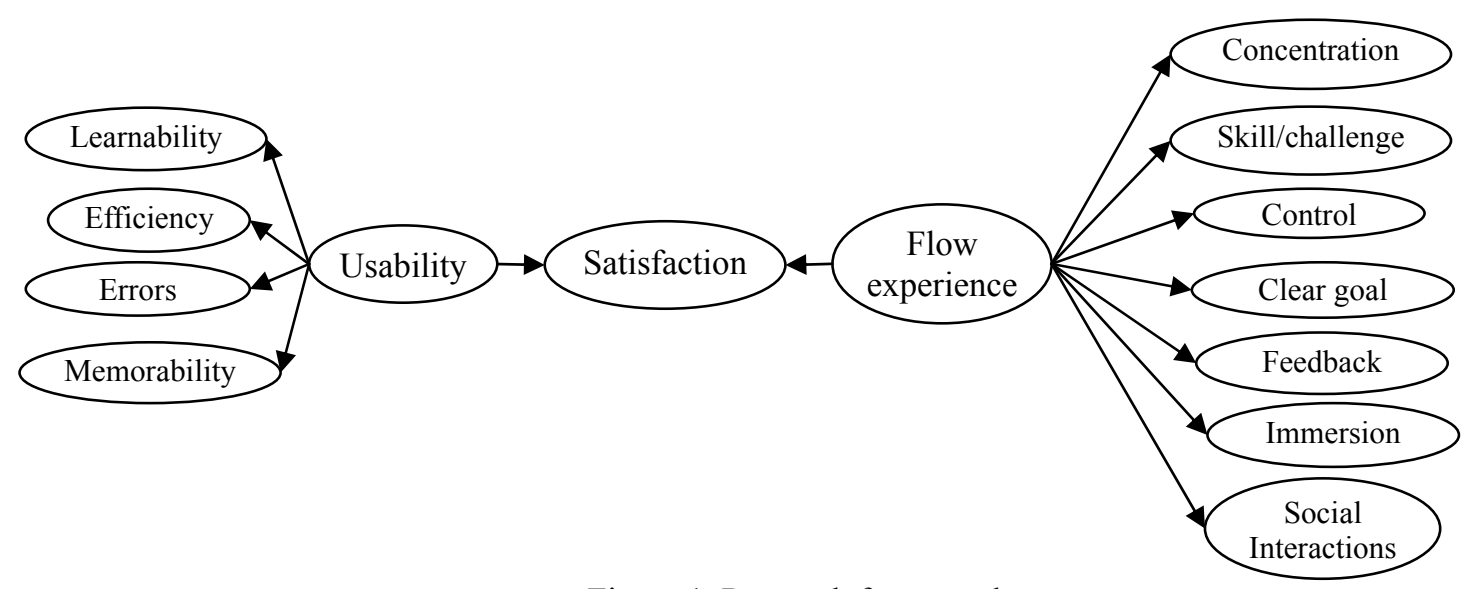

Figure 1. Research framework 
Table 3. Question items for measuring usability of mobile games

\begin{tabular}{|c|c|c|}
\hline & Question items & Literature \\
\hline Learnability & $\begin{array}{l}\text { - Familiar: ease of use of visual interface } \\
\text { - Logical: interactions compliable with standards and } \\
\text { conventions }\end{array}$ & $\begin{array}{l}\text { Nielsen (1994b), Nielsen and } \\
\text { Molich (1990), Korhonen and } \\
\text { Koivisto (2006) }\end{array}$ \\
\hline Efficiency & $\begin{array}{l}\text { - Effort-saving exploration: clear guides and instructions to } \\
\text { facilitate interactions } \\
\text { - Agile operation: proficiently control user interface in hand } \\
\text { - Expected response: interaction without time lag, confusion, } \\
\text { or hesitation }\end{array}$ & $\begin{array}{l}\text { Agarwal and Venkatesh (2002), } \\
\text { Nielsen(1994b)' Korhonen and } \\
\text { Koivisto (2006) }\end{array}$ \\
\hline Errors & $\begin{array}{l}\text { - Error elimination: quick recovering strategy against bugs } \\
\text { - Error prevention: helpful instructions for preventing } \\
\text { irreversibility }\end{array}$ & $\begin{array}{l}\text { Nielsen(1994b), Korhonen and } \\
\text { Koivisto (2006), Su (2006) }\end{array}$ \\
\hline Memorability & $\begin{array}{l}\text { - Intelligent setting: conveniently and smoothly adjusting } \\
\text { environmental settings } \\
\text { - Prompt notification: quick hints and references for } \\
\text { proceeding interactions }\end{array}$ & $\begin{array}{l}\text { Nielsen and Molich(1990), } \\
\text { Korhonen and Koivisto (2006), } \\
\mathrm{Su}(2006)\end{array}$ \\
\hline
\end{tabular}

\subsection{Measurements of Mobile Flow}

Table 4 lists question items of mobile flow experience. The concentration element includes items about diverse stimuli, consistant theme, meaningful storyline, and worthy encumberance. Matching between skill and challenge concerns grading game challenge, practice opportunity, and non-repetitive tasks. The clear goal emphasizes sequential targets and involvement. The control property focuses on comfortable operation and expected role of the game, while the feedback mechanism concerns in-time response, rewarding incentive, and competitive progress. Immersion includes items of time distortion, surroundiong ignorance, and provoking emotion of the game. Finally, the social interaction property considers co-opetition interaction, communication, and emulation.

Table 4. Question items for measuring flow of mobile games

\begin{tabular}{|c|c|c|}
\hline & ns & ture \\
\hline on & $\begin{array}{l}\text { Diverse stimuli: mobile game contains many sources of } \\
\text { audio or visual curiosities } \\
\text { - Consistent theme: consistency promotes prospect and } \\
\text { proficiency } \\
\text { - Meaningful storyline: a strict storyline encourages } \\
\text { interaction } \\
\text { - Worthy encumberance: memorization, recognition, and } \\
\text { physical loading for concentration }\end{array}$ & $\begin{array}{l}\text { Csikszentmihaly } \\
\text { (1990), Novak et al. } \\
\text { (2000), Ghani and } \\
\text { Deshpande (1994), } \\
\text { Sweetser and Wyeth } \\
\text { (2005), Korhonen and } \\
\text { Koivisto (2006) }\end{array}$ \\
\hline Skill/ challenge & $\begin{array}{l}\text { - Discriminatory challenge: adjusting the game challenge } \\
\text { according to player proficiency } \\
\text { - Practice makes perfect: skill can be drilled } \\
\text { - Non-repetitive task: no boring practices to hinder } \\
\text { achievement }\end{array}$ & $\begin{array}{l}\text { Csikszentmihaly } \\
\text { (1990), Sweetser and } \\
\text { Wyeth (2005), } \\
\text { Korhonen and } \\
\text { Koivisto(2006) }\end{array}$ \\
\hline
\end{tabular}




\begin{tabular}{|c|c|c|}
\hline Control & $\begin{array}{l}\text { - Comfortable operation: reckoning challenges easily with } \\
\text { a high level of knowledge and freedom } \\
\text { - Expected role playing: interacting with qualified } \\
\text { competence }\end{array}$ & $\begin{array}{l}\text { Csikszentmihaly } \\
\text { (1990), Novak et al. } \\
\text { (2000), Trevino and } \\
\text { Webster (1992) }\end{array}$ \\
\hline Clear goal & $\begin{array}{l}\text { Sequence: upgrading and notifying the goals of sequential } \\
\text { challenges in time } \\
\text { - Involvement: supporting participants to set up goals and } \\
\text { strategies }\end{array}$ & $\begin{array}{l}\text { Sweetser and Wyeth } \\
(2005), \text { Korhonen and } \\
\text { Koivisto (2006) }\end{array}$ \\
\hline Feedback & $\begin{array}{l}\text { - Response in time: consequences of strategic interactions } \\
\text { should be notified immediately } \\
\text { - Rewarding incentive: compensation for achievement, } \\
\text { accumulative experience, and loyalty } \\
\text { - Competitive progress: encouraging peer competition and } \\
\text { benchmarking performance }\end{array}$ & $\begin{array}{l}\text { Csikszentmihalyi } \\
\text { (1990), Sweetser and } \\
\text { Wyeth (2005), } \\
\text { Korhonen and } \\
\text { Koivisto (2006) }\end{array}$ \\
\hline Immersion & $\begin{array}{l}\text { - Surrounding ignorance: paying attention only to playing } \\
\text { regardless of changes in environmental context } \\
\text { - Time distortion: a craving for unceasing playing even with } \\
\text { time elapse } \\
\text { - Provoking emotion: passion of the game engaged along a } \\
\text { series of emerging climaxes }\end{array}$ & $\begin{array}{l}\text { Csikszentmihalyi (199 } \\
\text { 0), Hoffman and } \\
\text { Novak (1996), } \\
\text { Sweetser and Wyeth } \\
\text { (2005) }\end{array}$ \\
\hline $\begin{array}{l}\text { Social } \\
\text { interaction }\end{array}$ & $\begin{array}{l}\text { - Co-opetition: promoting players to compete and cooperate } \\
\text { strategically } \\
\text { - Communication and emulation: allowing players to } \\
\text { dialogue, discuss, and mutually encourage }\end{array}$ & $\begin{array}{l}\text { Sweetser and Wyeth } \\
(2005) \text {, Weibel et al. } \\
\text { (2008), Pagulayan et } \\
\text { al. (2003) }\end{array}$ \\
\hline
\end{tabular}

\subsection{Building Hypotheses}

According to the literature review, usability is positively related to mobile services with more power than the traditional TAM (Venkatesh et al., 2003; Venkatesh \& Ramesh, 2006). Therefore, this study proposes the following hypotheses:

$\mathbf{H}_{1}$ : Mobile game usability is positively related to mobile gaming satisfaction.

Table 3 demonstrates the measurement items of learnability, efficiency, errors, and memorability, which enable achieving the goal of usability. Hence, these four elements have a positive relationship with mobile gaming usability to enhance mobile gaming satisfaction.

$\mathbf{H}_{1 \mathrm{a}}$ : Mobile game learnability is positively related to mobile usability.

$\mathbf{H}_{1 b}$ : Mobile game efficiency is positively related to mobile usability.

$\mathbf{H}_{1 \mathrm{c}}$ : Mobile game error is positively related to mobile usability.

$\mathbf{H}_{1 \mathrm{~d}}$ : Mobile game memorability is positively related to mobile usability.

The flow experience enhances the playability and enjoyment of mobile gaming, and increases user satisfaction (Korhonen \& Koivisto, 2006; Ha et al., 2007). Therefore the following hypothesis:

$\mathbf{H}_{2}$ : Mobile game flow is positively related to mobile gaming satisfaction.

Table 4 shows the measurement items of concentration, matching between skill and challenge, control, clear goal, feedback, immersion, and social interactions, which help forward mobile gaming flow. This research demonstrates the following hypotheses.

$\mathbf{H}_{2 \mathrm{a}}$ : Mobile game concentration is positively related to mobile flow

$\mathbf{H}_{2 \mathrm{~b}}$ : Mobile game matching between skill and challenge is positively related to mobile flow. 
$\mathbf{H}_{2 \mathrm{c}}$ : Mobile game control is positively related to mobile flow.

$\mathbf{H}_{2 \mathrm{~d}}$ : Mobile game clear goal is positively related to mobile flow.

$\mathbf{H}_{2 \mathrm{e}}$ : Mobile game feedback is positively related to mobile flow.

$\mathbf{H}_{2 \mathrm{f}}$ : Mobile game immersion is positively related to mobile flow.

$\mathbf{H}_{2 \mathrm{~g}}$ : Mobile game social interaction is positively related to mobile flow.

\section{Data Collection and Analysis}

\subsection{Sample of Mobile Games}

The study investigated the most popular mobile game websites in Taiwan, Gamebase and Mpbus, to uncover key types of mobile games. The Gamebase website classifies mobile games into five categories: sports, strategist, causal, puzzle, and adventure. According to the top ten downloaded games, seven of ten (70\%) belong to puzzles, while the other three (30\%) are adventures (Gamebase, 2009). The Mpbus website groups mobile games into seven types: shooting, adventure, RPG, puzzle, sports, causal, and adult games (Mpbus, 2009). Sixty percent of most downloaded games in the Mpbus are RPG and adventure, while $30 \%$ are the causal type. For similarity, this study grouped the puzzle game and the causal one together and renamed it as the causal-puzzle type, while the RPG game and the adventurous one were grouped into the RPG-adventure type. After rough estimation, the causal-puzzle mobile game occupied $50 \%(0.5 \times 70 \%+0.5 \times 30 \%)$ of the market while the RPG-adventure one occupied $45 \%(0.5 \times 30 \%+0.5 \times 60 \%)$. The $95 \%$ share is close to the total mobile gaming market. Thus, this study focused on these two types of mobile games and examined the influences of usability and flow on mobile gaming satisfaction.

This study designed a questionnaire webpage and posted response invitations on several main Bulletin Board Stations (BBSs) and community websites in Taiwan. The sampling process ran from April 1 to May 20, 2009. The online survey began with discriminating the mobile gaming experience of respondents to the causal-puzzle or the RPG-adventure and proceeded with question answering. Finally, the total sample size was 994 . The valid sample was 813 because of 181 incomplete responses. There were totally 541 respondents answering the mobile causal-puzzle gaming experience, and 272 for the RPG-adventure type.

Most respondents were young men with college degrees (72.57\%). The main demographic sector was 20- to 29 -year-olds $(85.6 \%)$. Most mobile players had five years of mobile game experience (about $41.82 \%$ ) and currently played mobile games one hour per day (71.71\%). Significantly, most mobile gamers were also PC-based game players, except for a small portion of interviewees $(7.74 \%)$ who only played mobile games.

\subsection{Measurement Reliability}

This study examined the measurement reliability of usability and flow. The higher CR (composite reliability) value is better (Fornell \& Larcker, 1981). Table 5 shows that all CR values are higher than 0.6 , which is typically the bottom line for reliable measurement (Hair et al., 2006).

\subsection{Measurement Validity}

The average variance extracted (AVE) values shown in Table 5 also exceeded 0.50 , indicating convergence validity of the measurements (Fornell \& Larcker, 1981). Table 6 also shows the factor loadings resulted from confirmatory factor analysis. Most question items demonstrate high measurement validity of constructs for their loadings higher than 0.70. (Hair et al., 2006)

Table 5. Evaluation of measurements

\begin{tabular}{lll}
\hline Construct & CR & AVE \\
\hline Learnability & 0.745 & 0.783 \\
Efficiency & 0.797 & 0.751 \\
Errors & 0.731 & 0.740 \\
Memorability & 0.790 & 0.844 \\
Concentration & 0.893 & 0.677 \\
Skill/challenge & 0.773 & 0.707 \\
Control & 0.789 & 0.840 \\
Clear goal & 0.701 & 0.715 \\
Feedback & 0.758 & 0.704 \\
Immersion & 0.744 & 0.654 \\
Social interactions & 0.755 & 0.798 \\
Satisfaction & 0.790 & 0.570 \\
\hline
\end{tabular}




\subsection{Hypotheses Testing}

Using AMOS software, two structural equation models (SEM) examined the relationship between usability, flow, and satisfaction for the causal-puzzle and RPG-adventure mobile games respectively. The results show the modelling significance of both. Table 7 indicates that several important goodness-of-fit indices lie in the suggested range (Hair et al., 2006). Thus, this study shows the powerful relationship between usability, flow, and satisfaction for two types of mobile games.

For the causal-puzzle type of mobile game, the left part of Figure 2 shows that the SEM approach reveals a positive relationship between usability and mobile gaming satisfaction with a significant structural coefficient, .44, which supports $\mathrm{H}_{1}$. The path coefficients of learnability, efficiency, errors, and memorability are $.68, .79, .94$, and .7 , respectively, supporting the four sub-hypotheses $\mathrm{H}_{1 \mathrm{a}}$ through $\mathrm{H}_{1 \mathrm{~d}}$ (Schumacker \& Lomax, 1996; Hair et al., 2006). Higher usability promotes higher mobile gaming satisfaction. Similarly, the right part of Figure 2 shows that flow also supports hypotheses $\mathrm{H}_{2}, \mathrm{H}_{2 \mathrm{a}}$ through $\mathrm{H}_{2 \mathrm{~g}}$.

For the RPG-adventure type of mobile game, Figure 3 reveals positive relationships from usability and flow to satisfaction with two higher and significant structural coefficients, .51 and .60 , respectively, than that of the causal-puzzle type. All the hypotheses are supported in the case of the RPG-adventure type.

\section{Discussion}

The Tucker-Lewis index (TLI) indicates that when the LTI value approaches 0 , the null SEM model will be highly different from the alternative one. For the other case of a near-to-1 LTI value, these two SEM models seem to be the same. The TLI value is equal to $\left[\left(\chi_{\text {null }}^{2} / d f_{\text {null }}\right)-\left(\chi_{\text {alternative }}^{2} / d f_{\text {alternative }}\right)\right] /\left[\left(\chi_{\text {null }}^{2} / d f_{\text {null }}\right)-1\right]$, of which the value of $\chi^{2} / d f$ is one of the goodness-of-fit indices of SEM (Schumacker \& Lomax, 1996). This research derived a TLI of .25. This small value is likely to indicate that these two SEM models perform differently, even though they both reveal significant relationships between usability, flow, and satisfaction. The radar map of Figure 4 indicates the first-stage factor scores, and the RPG-adventure type mobile game resorts to more learnability and error tolerance, and appeals to a higher degree of concentration, matching between skill and challenge, comfortable controlling, in-time notification of clear goals, and feedback mechanism. Kassulke (2007) argues that under the mobile context, these two types of mobile games need various emphases to increase player satisfaction.

Table 6. Confirmatory factor analysis and associated factor loadings

\begin{tabular}{|c|c|c|c|c|c|c|c|c|c|c|c|c|}
\hline $\begin{array}{l}\text { Question } \\
\text { items }\end{array}$ & 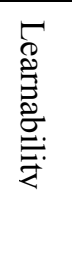 & 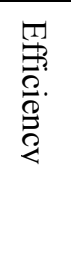 & $\begin{array}{l}\frac{\pi}{9} \\
\overrightarrow{0} \\
0\end{array}$ & 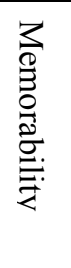 & $\begin{array}{l}\delta \\
\stackrel{0}{0} \\
\stackrel{0}{0} \\
\stackrel{0}{0} \\
\stackrel{0}{0}\end{array}$ & 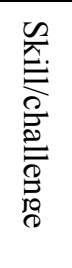 & $\begin{array}{l}\Omega \\
\stackrel{0}{0} \\
0\end{array}$ & $\begin{array}{l}\Omega \\
\mathcal{D} \\
\stackrel{0}{7} \\
0 \\
0 \\
0\end{array}$ & 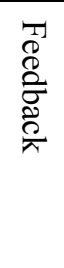 & 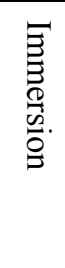 & 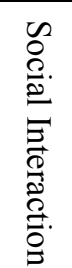 & 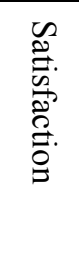 \\
\hline Familiar & .76 & & & & & & & & & & & \\
\hline Logical & .78 & & & & & & & & & & & \\
\hline Effort-saving exploration & & .74 & & & & & & & & & & \\
\hline Agile operation & & .75 & & & & & & & & & & \\
\hline Expected response & & .77 & & & & & & & & & & \\
\hline Error elimination & & & .87 & & & & & & & & & \\
\hline Error prevention & & & .64 & & & & & & & & & \\
\hline Intelligent setting & & & & .84 & & & & & & & & \\
\hline Prompt notification & & & & .78 & & & & & & & & \\
\hline Diverse stimuli & & & & & .75 & & & & & & & \\
\hline Consistent theme & & & & & .80 & & & & & & & \\
\hline Meaningful storyline & & & & & .63 & & & & & & & \\
\hline Worthy encumbrance & & & & & .68 & & & & & & & \\
\hline Discriminatory challenge & & & & & & .72 & & & & & & \\
\hline Practice makes perfect & & & & & & .73 & & & & & & \\
\hline Non-repetitive task & & & & & & .74 & & & & & & \\
\hline
\end{tabular}


Expected role playing

Comfortable operation

Goal sequence

Involvement

Response in time

Rewarding incentive

Competitive progress

Surrounding ignorance

Time distortion

Provoking emotion

Co-opetition

Communication and emulation

Persistence of use

Willingness to try

Intention of recommendation
.83

.78

.78

.69

.74

.66

.78

.64

.72

.74

.77

.78

Table 7. Goodness of fit of SEM

\begin{tabular}{lccc}
\hline Goodness of Fit indices & $\begin{array}{c}\text { The causal-puzzle } \\
\text { mobile game }\end{array}$ & $\begin{array}{c}\text { The RPG-adventure } \\
\text { mobile game }\end{array}$ & $\begin{array}{c}\text { Significance } \\
\text { Thresholds }\end{array}$ \\
\hline$\chi^{2 /(\text { degree of freedom) }}$ & 2.41 & 2.05 & $<5.00$ \\
GFI & 0.908 & 0.917 & $>0.8$ \\
AGFI & 0.88 & 0.892 & $>0.8$ \\
NFI & 0.9 & 0.908 & $>0.9$ \\
CFI & 0.902 & 0.922 & $>0.9$ \\
RMSEA & 0.055 & 0.051 & $<0.08$ \\
\hline
\end{tabular}

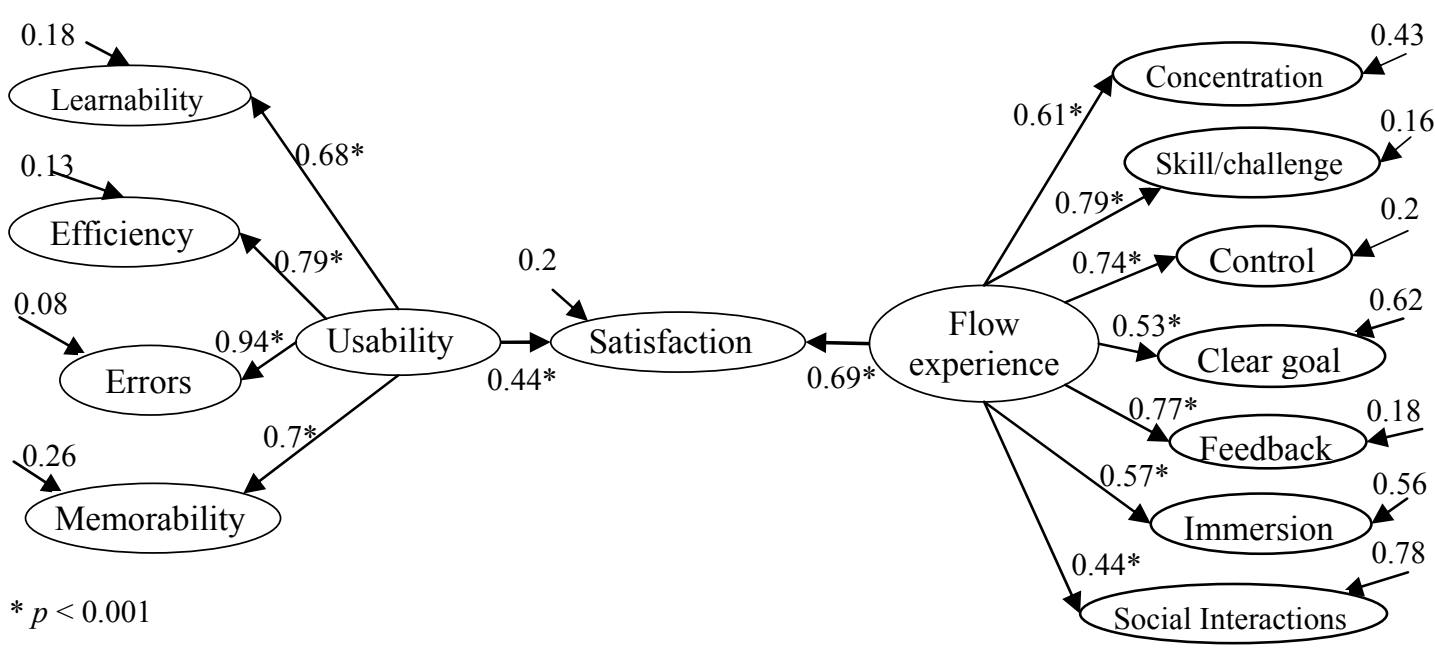

Figure 2. SEM results of usability, flow, and satisfaction for the causal-puzzle type of mobile game 


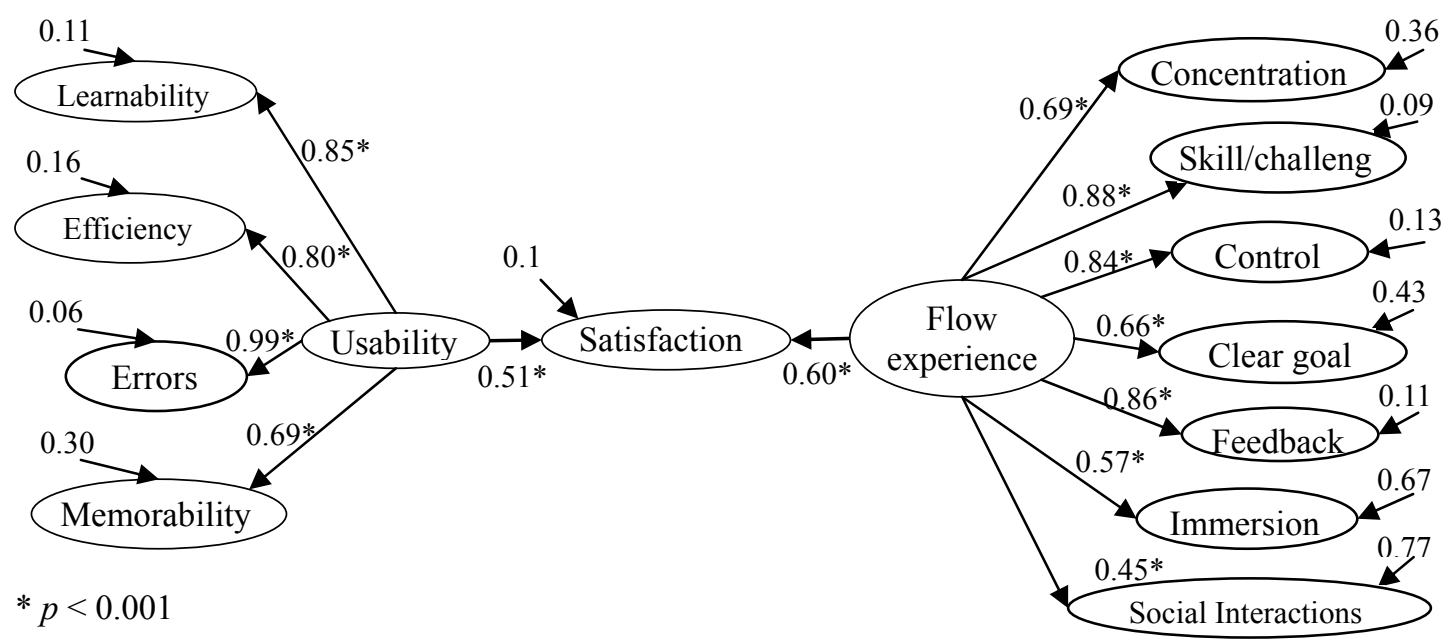

Figure 3. SEM results of usability, flow, and satisfaction for the RPG-adventure type of mobile game

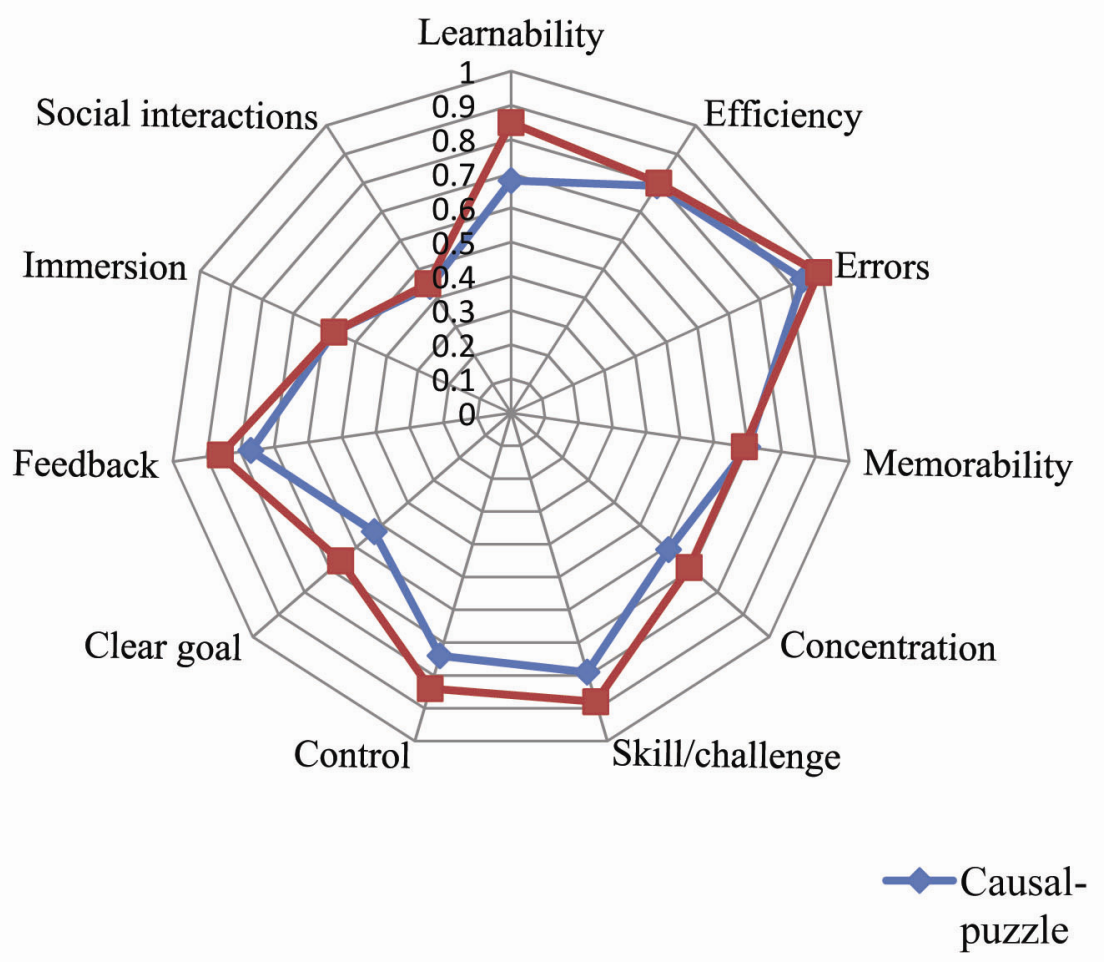

Figure 4. The radar map of usability and flow for two key types of mobile game

\section{Conclusions}

\subsection{Research Implications}

This paper integrates usability and flow to explain mobile gaming satisfaction and finds that the RPG-adventure type game claims more usability and flow experience than the causal-puzzle one. The research contributes to academia as the first to combine usability and flow in explaining mobile gaming satisfaction. The highly interactive gaming design demands adopting the usability criterion not emphasized in the popular TAM, and the flow factor in the mobile context for mobile computing specialties.

The integrative model also provides practical implications to industry players. The valid measurement items for usability and flow can help mobile gaming vendors improve interface designs. Hence, developing a mobile game with high usability using familiar and logical interaction, effort-saving and agile exploration, reactions under 
expectation, quick error elimination and prevention, and hints anytime and anywhere, will be applausive to mobile gamers. Creating a mobile game with an impressive flow using a consistent theme consisting of diverse stimuli, a challengeable game rating system, a rewarding incentive, and even a user interface allowing mutual communication, collaboration, and emulation will be attractive to mobile gamers. The RPG-adventure mobile game vendors need to particularly strengthen some characteristics of usability and flow in contrast to the causal-puzzle mobile game.

Because most mobile gamers investigated in this study also played PC-based online games (92.3\%), mobile game vendors need to elaborate a migration strategy to attract existing large-scale PC-based online gamers without losing usability and flow as that in the fixed-line network. However, it is difficult for a game vendor to solely fulfill all the requisites of mobile gaming services because the complete mobile gaming product needs diverse complements (Steinbock, 2002; Hung \& Yeh, 2007; Multimedia Research Consultancy, 2008). For example, mobile phone manufacturers and mobile operators both have influence on installation of client-side applications (Funk, 2002). Hence, mobile game vendors need to create a triangle win-win-win cooperation among them. Mobile game vendors should coordinate with mobile phone manufacturers for large-sized screens, touch screens, high-powered battery, and voice-controlled interface to help mobile players achieve learnability, ease of use, comfortable operations, controllability, and concentration and immersion in their mobile flow experience. Cooperating for higher computing power and memory capacity is also useful for mobile players to garner memorability, eliminate errors, and immediate feedback. Low-priced and broadband wireless services supported by cooperative mobile operators will facilitate mobile gamers, particularly for RPG-adventure mobile gamers, to experience the flow of concentration, immersion, and social interactions without worrying about disconnection.

\subsection{Research Limits}

This research collected data simply by investigating past mobile experience rather than an instant experiment using a particular mobile game. Even though the latter decreases dispersion resulting from individual bias of mobile experience and recall error of time lag, it is a time-consuming and high-cost approach. Respondents were existing mobile lovers and often surf in the mobile gaming community. Thus, the results may only reflect the satisfactory degree of existing users rather than the voices of new ones. Future research can reach to non-mobile gaming users to supplement to this study of existing users.

\section{References}

Agarwal, R., \& Venkatesh, V. (2002). Assessing a firm's web presence: A heuristic evaluation procedure for the measurement of usability. Information System Research, 13(2), 168-186. http://dx.doi.org/10.1287/isre.13.2. 168.84

Ardito, C., Marsico, M. D., \& Lanzilotti, R. (2004). Usability of e-learning tools. Proceedings of Working Conference on Advanced Visual Interfaces: AVI'04 (pp.25-28), Gallipoli. http://dx.doi.org/10.1145/989863. 989873

Beck, J., \& Wade, M. (2003). DoCoMo: Japan's Wireless Tsunami. NY: AMACOM.

Bernhaupt, R., Obrist, M., \& Tscheligi, M. (2007). Usability and usage of iTV services: Lessons learned in an Austrian field trial. ACM Computers in Entertainment, 5(2), 1-14. http:// dx.doi.org/10.1145/1279540.1279 546

Buchanan, G., Farrant, S., Jones, M., Thimbleby, H., Marsden, G., \& Pazzani, M. (2001). Improving mobile Internet usability. Proceedings of the 10th international conference on World Wide Web (pp.673 - 680). Hong Kong. http://dx.doi.org/10.1145/371920.372181

Budiu, R., \& Nielsen, J. (2010). Usability of iPad apps and websites. Nielsen Norman Group. Retrieved April 7, 2010, from http://www.nngroup.com/reports/mobile/ipad/

Choi, D. H., Kim, J., \& Kim, S. H. (2007). ERP training with a web-based electronic learning system: The flow theory perspective. International Journal of Human-Computer Studies, 65(3), 223-243. http://dx.doi.org/10. 1016/j.ijhcs.2006.10.002

Chen, C. H., Sun, C. T., \& Hsieh, J. (2008a). Player guild dynamics and evolution in massively multiplayer online games. CyberPsychology \& Behaviour, 11(3), 293-301. http://dx.doi.org/10.1089/cpb.2007.0066

Chen, K., Yen, D. C., Hung, S. Y., \& Huang, A. H. (2008b). An exploratory study of the selection of communication media: The relationship between flow and communication outcomes. Decision Support Systems, 45(4), 822-832. http://dx.doi.org/10.1016/j.dss.2008.02.002 
Clarke, S. G., \& Haworth, J. T. (1994). 'Flow' experience in the daily lives of sixth-form collect students. British Journal of Psychology, 85, 511-523. http://dx.doi.org/10.1111/j.2044-8295.1994.tb02538.x

Constantiou, I. D., Damsgaard, J., \& Knutsen, L. (2007). The four incremental steps toward advanced mobile service adoption. Communications of the ACM, 50(6), 51-55. http://dx.doi.org/10.1145/1247001.1247005

Csikszentmihalyi, M. (1975). Beyond Boredom and Anxiety. San Francisco, CA: Jossey-Bass.

Csikszentmihalyi, M., \& Csikszentmihalyi, I. (1988). Optimal Experience: Psychological Studies of Flow in Consciousness. New York, NY: Cambridge University Press.

Csikszentmihalyi, M. (1990). Flow: The Psychology of Optimal Experience. New York, NY: Harper and Row.

Davis, F. D. (1989). Perceived usefulness, perceived ease of use and user acceptance of information technology. MIS Quarterly, 13(3), 319-339. http://dx.doi.org/10.2307/249008

Edwards, P. J., Moloney, K. P., Jacko, J. A., \& Sainfort, F. (2008). Evaluating usability of a commercial electronic health record: A case study. International Journal of Human-Computer Studies, 66(10), 718-728. http://dx.doi.org/10.1016/j.ijhcs.2008.06.002

Eshghi, A., Haughton, D., \& Topi, H. (2007). Determinants of customer loyalty in the wireless telecommunications industry. Telecommunications Policy, 31(2), 93-106. http://dx.doi.org/10.1016/j.telpol. 2006.12.005

Fornell, C., \& Larcker, D. F. (1981). Structural equation models with unobservable variables and measurement error: Algebra and statistics. Journal of Marketing Research, 18(3), 382-388. http://dx.doi.org/10.2307/315 0980

Funk, J. L. (2002). Global Competition Between and Within Standards: The Case of Mobile Phones. NY: Palgrave.

Gamebase. (2009). Top 10 mobile games. Retrieved April 10, 2010, from http://gamebase.somuch.com.tw/

Ghani, J. A., \& Deshpand, S. P. (1994). Task characteristics and the experience of optimal flow in human-computer interaction. The Journal of Psychology, 128(4), 381-391. http://dx.doi.org/10.1080/00223 980.1994 .9712742

Gray, W. D., \& Salzman, M. C. (1998). Damaged merchandise? A review of experiments that compare usability evaluation methods. Human-Computer Interaction, 13(3), 203-261. http://dx.doi.org/10.1207/s15327051hci 1303_2

Ha, I., Yoom, Y., \& Choi, M. (2007). Determinants of adoption of mobile broadband wireless access environment. Information \& Management, 44(3), 276-286. http://dx.doi.org/10.1016/j.im.2007.01.001

Hair, J. F., Anderson, R. E., Tatham, R. L., \& Black, W. C. (2006). Multivariate Data Analysis. $6^{\text {th }}$ ed., Englewood Cliffs, NJ: Prentice-Hall.

Hoffman, D. L., \& Novak, P. T. (1996). Marketing in hypermedia computer-mediated environments: Conceptual foundations. Journal of Marketing, 60(3), 50-68. http://dx.doi.org/10.2307/1251841

Hsu, C. L., \& Lu, H. P. (2003). Why do people play online games? An extended TAM with social influences and flow experience. Information \& Management, 41(7), 853-868. http://dx.doi.org/10.1016/j.im.2003.08.014

Hung, C. L., \& Yeh, S. Y. (2007). The diffusion of i-Mode overseas: A perspective of institutional differences. International Journal of Innovation and Technology Management, 4(1), 69-86. http://dx.doi.org/10.1142/S0 219877007000916

Karat, J. (1997). Evolving the scope of user-centered design. Communications of ACM, 40(7), 33-38. http://dx. doi.org/10.1145/256175.256181

Kassulke, M. (2007). Casual games slow down innovation and growth of mobile games Market! Retrieved April 11, 2009, from http://mobilegames.blogs.com/mobile_games_blog/2007/03/open_discussion.html\#ixzz0ul nbKDyX

Keeker, K. (1997). Improving Web-site usability and appeal: Guidelines compiled by MSN usability research. Retrieved April 7, 2009, from http://msdn.microsoft.com/en-us/library/cc889361(office.11).aspx

Klimmt, C., Hartmann, T., \& Frey, A. (2007). Effectance and control as determinants of video game enjoyment. CyberPsychology \& Behavior, 10(6), 845-848. http://dx.doi.org/10.1089/cpb.2007.9942. 
Klimmt, C., Rizzo, A., Vorderer, P., Koch, J., \& Fischer, T. (2009). Experimental evidence for suspense as determinant of video game enjoyment. CyberPsychology \& Behaviour, 12(1), 29-31. http://dx.doi.org/10. 1089/cpb.2007.9942

Korhonen, H., \& Koivisto, E. M. I. (2006). Playability heuristics for mobile games. Proceedings of the 8th International Conference on Human-Computer Interaction with Mobile Devices and Services: MobileHCI'06 (pp.12-15), Helsinki. http://dx.doi.org/10.1145/1152215.1152218

Koufaris, M. (2002). Applying the technology acceptance model and flow theory to online consumer behaviour. Information System Research, 13(2), 205-223. http://dx.doi.org/10.1287/isre.13.2.205.83

Lee, G., Eastman, C. M., Taunk, T., \& Ho, C. H. (2010). Usability principles and best practices for the user interface design of complex 3D architectural design and engineering tools. International Journal of Human-Computer Studies, 68(1-2), 90-104. http://dx.doi.org/10.1016/j.ijhcs.2009.10.001

Looije, R., Brake, G. M., \& Neerincx, M. A. (2007). Usability engineering for mobile maps. Proceedings of the 4th International Conference on Mobile Technology, Applications, and Systems: Mobility'07 (pp.10-12), Singapore. http://dx.doi.org/10.1145/1378063.1378150

Lutz, R. J., \& Guiry, M. (1994). Intensive consumption experiences: peaks, performances, and flows. Proceedings of Winter Marketing Educators' Conference, St. Petersburg, FL.

Massimini, F., \& Carli, M. (1988). The systematic assessment of flow in daily experience. In M. Csikszentmihalyi, \& I. Csikszentmihalyi (Eds.), Optimal Experience: Psychological Studies of Flow in Consciousness (pp.288-306). NY: Cambridge University Press.

Messerschmitt, D. G., \& Szyperski, C. (2003). Software ecosystem: Understanding an indispensable technology and industry. Cambridge, MA: MIT Press.

Mohr, J., Sengupta, S., \& Slater, S. (2010). Marketing of High-technology Products and Innovations ( ${ }^{\text {rd }}$ ed.). Prentice-Hall.

Moon, J. W., \& Kim, Y. G. (2001). Extending the TAM for a world-wide-web context. Information \& Management, 38(4), 217-230. http://dx.doi.org/10.1016/S0378-7206(00)00061-6

Mpbus. (2009). Bulletin of most downloaded. Retrieved April 11, 2010, from http: //www.mpbus.com/

Multimedia Research Consultancy. (2008). The Global Mobile Games Industry - 10 Years On! Retrieved April 11, 2010, from http://www.multimedia-research.com

Nielsen, J. (1994a). Enhancing the explanatory power of usability heuristics. Proceedings of the SIGCHI Conference on Human Factors in Computing Systems (pp.152-158). http://dx.doi.org/ 10.1145/191666.191 729

Nielsen, J. (1994b). Usability Engineering. Morgan Kaufmann Publishers.

Nielsen, J., \& Molich, R. (1990). Heuristic evaluation of user interfaces. Proceedings of the SIGCHI Conference on Human Factors in Computing Systems: Empowering People (pp.249-256). http:// dx.doi.org/10.1145/97 243.97281

Nielsen, J., \& Loranger, H. (2006). Prioritizing web usability. Berkeley, CA: New Riders.

Noiwan, J., \& Norcio, A. F. (2006). Cultural differences on attention and perceived usability: Investigating colour combinations of animated graphics. International Journal of Human-Computer Studies, 64(2), 103-122. http://dx.doi.org/10.1016/j.ijhcs.2005.06.004

Novak, T. P., Hoffman, D. L., \& Yung, Y. F. (2000). Measuring the customer experience in online environments: A structural modelling approach. Marketing Science, 19(1), 22-42. http://dx.doi.org/10.1287/mksc.19.1.22. 15184

Oliver, R. L. (1997). Satisfaction: A Behavioural Perspective on the Consumer. New York, NY: Irwin/McGraw-Hill.

Pace, S. (2004). A grounded theory of the flow experiences of Web users. International Journal of Human-Computer Studies, 60(3), 327-363. http://dx.doi.org/10.1016/j.ijhcs.2003.08.005

Pagulayan, R., Keeker, K., Wixon, D., Romero, R., \& Fuller, T. (2003). User-centered design in games. In J.A. Jacko, \& A. Sears (Eds.), The Human-computer Interaction Handbook: Fundamentals, Evolving Techniques and Emerging Applications (pp. 883-905). NJ: Lawrence Erlbaum Associates. 
Peevers, G., Douglas, G., \& Jack, M. A. (2007). A usability comparison of three alternative message formats for an SMS banking service. International Journal of Human-Computer Studies, 66(2), 113-123. http://dx.doi. org/10.1016/j.ijhcs.2007.09.005

Pettey, C., \& Tudor, B. (2010). Competitive landscape: mobile devices, worldwide, 4Q09 and 2009. Gartner Report.

Pilke, E. M. (2004). Flow experiences in information technology use. International Journal of Human-Computer Studies, 61(3), 347-357. http://dx.doi.org/10.1016/j.ijhcs.2004.01.004

Pyramid Research. (2009). Mobile gaming in emerging markets: Five-year forecast and impact analysis. Retrieved April 11, 2010, from http://www.researchandmarkets.com/research/aadda9/mobile_gaming_in_e

Rai, A., \& Sambamurthy, V. (2006). The growth of interest in services management: opportunities for information systems scholars. Information Systems Research, 17(4), 327-331. http://dx.doi.org/10.1287/isre. 1060.0108

Reisinger, D. (2009). Microsoft, Palm, RIM need better mobile Apps to catch Apple`s iPhone. eweek.com, Retrieved from http://www.eweek.com/c/a/Mobile-and-Wireless/Microsoft-Palm-RIM-Need-Better-Mobile-Apps-to-Catch -Apples-iPhone-258249 (April 11, 2010).

Reisinger, D. (2010). 10 reasons why RIM beats Google, Apple at the mobile game. eweek.com, Retrieved from $\mathrm{http} / / / \mathrm{www}$. eweek.com/c/a/Mobile-and-Wireless/10-Reasons-Why-RIM-Beats-Google-Apple-at-the-Mobil e-Game-756385 (April 11, 2010).

Ryan, C., \& Gonsalves, A. (2005). The effect of context and application type on mobile usability: An empirical study. ACSC '05 Proceedings of the Twenty-eighth Australasian Conference on Computer Science, 38, (pp.115-124), Darlinghurst, Australia.

Sauro, J., \& Kindlund, E. (2005). A method to standardize usability metrics into a single score. Proceedings of ACM Conference on Human Factors in Computing Systems: ACM CHI'05 (pp.2-7), Portland. http://dx.doi.org/10.1145/1054972.1055028

Schumacker, R. E., \& Lomax, R. G. (1996). A beginner's guide to structural equation modelling. NJ: Lawrence Erlbaum Associates.

Steinbock, D. (2002). Wireless horizon: Strategy and competition in the worldwide mobile marketplace. New York, NY: AMACOM.

$\mathrm{Su}$, D. K. S. (2006). Usability guidelines for designing mobile learning portals. Proceedings of the 3th International Conference on Mobile Technology, Applications, and Systems: Mobility'06 (pp.25-27), Bangkok. http://dx.doi.org/10.1145/1292331.1292359

Sweetser, P., \& Wyeth, P. (2005). GameFlow: A model for evaluating player enjoyment in games. $A C M$ Computers in Entertainment, 3(3), 1-24. http://dx.doi.org/10.1145/1077246.1077253

Teece, D. J. (1986). Profiting from technological innovation: Implications for integration, collaboration, licensing and public policy. Research Policy, 15(6), 285-305. http://dx.doi.org/10.1016/0048-7333(86)900 27-2

Trevino, L. K., \& Webster, J. (1992). Flow in computer-mediated communication: electronic mail and voice mail evaluation and impacts. Communication Research, 19(5), 39-573. http://dx.doi.org/10.1177/0093650 92019005001

Venkatesh, V., Ramesh, V., \& Massey, A. P. (2003). Understanding usability in mobile commerce. Communications of the ACM, 46(12), 53-56. http://dx.doi.org/10.1145/953460.953488

Venkatesh, V., \& Ramesh, V. (2006). Web and wireless site usability: Understanding differences and modelling use. MIS Quarterly, 30(1), 181-206. http://www.jstor.org/stable/25148723

Webster, J., Trevino, L. K., \& Ryan, L. (1993). The dimensionality and correlates of flow in human-computer interactions. Computers in Human Behaviour, 9(4), 411-426. http://dx.doi.org/10.1016/0747-5632(93)9003 $2-\mathrm{N}$

Weibel, D., Wissmath, B., Habegger, S., Steiner, Y., \& Groner, R. (2008). Playing online games against computer- vs. human-controlled opponents: Effects on presence, flow, and enjoyment. Computers in Human Behaviour, 24(5), 2274-2291. http://dx.doi.org/10.1016/j.chb.2007.11.002 
Whitehead, C. (2006). Evaluating web page and web site usability. Proceedings of $44^{\text {th }}$ Southeast Conference: ACM SE'06 (pp. 10-12). Melbourne. http://dx.doi.org/10.1145/1185448.1185637

Wilson, R., Shortreed, J., \& Landoni, M. (2004). A study into the usability of E-encyclopedias. Proceedings of 2004 ACM symposium on applied computing: SAC'04 (pp.4-17), Nicosia. http://dx.doi.org/10.1145/967900. 968223

Wu, K. W., \& Ding, M. C. (2007). Validating the American consumer satisfaction index model in the online context: An empirical study of U.S. consumer electronics E-tailers. International Journal of Business and Information, 2(2), 199-220.

Zhang, P., Shelly, A., \& Sun, H. (2008). Two types of attitudes in ICT acceptance and use. International Journal of Human-Computer Interaction, 24(7), 628-648. http://dx.doi.org/10.1080/10447310802335482

Zhilin, Y., \& Robin, T. P. (2004). Consumer perceived value, satisfaction, and loyalty: the role of switching costs. Psychology \& Marketing, 21(10), 799-822. http://dx.doi.org/10.1002/mar.20030 